\title{
Sergej Sergel i Finnmark - en reisebeskrivelse fra 1907
}

\author{
Av Elena Glavatskaya og Gunnar Thorvaldsen \\ ELENA GLAVATSKAYA, Professor, Adr.: Institutt for historie, Urals føderale universitet, Lenins aveny 51, \\ Jekaterinburg, 620083, Russland. E-post: elena.glavatskaya@usu.ru
}

GUNNAR THORVALDSEn, Professor, Adr:: Registreringssentral for historiske data, Universitetet i Tromsø, Breiviklia, 9037 Tromsø. E-post: Gunnar.thorvaldsen@uit.no

Fra våren 1907 til februar 1908 foretok den russiske etnografen Sergej Sergel (1883-1955) en studiereise i Norden for å utøve deltakende observasjon og komplettere samlingen med samiske gjenstander ved Det russiske etnografiske museet (REM) i St Petersburg. Vårt hovedmål er å presentere Sergels erfaringer fra reisen ved å sette hans etterlatte materiale og forskning inn $i$ en sammenheng av norske kilder fra perioden, også for å øve kildekritikk. Dette har vært en mangel ved tidligere presentasjoner av hans etterlatte skrifter for et vestlig publikum, samtidig som disse er beheftet med flere misforståelser. Gjennom kildekritikken kan vi kaste lys over i hvilken grad Sergel hadde forutsetninger for å forstå den fremmede etniske sammenhengen han deltok i. Herunder vil vi forsøke å svare på om han virkelig var spion slik mange av dem han møtte trodde. I noen grad vil vi og vurdere hvilket inntrykk han fikk av samisk kultur og befolkning.

\section{Historiografi og forskningsmetode}

I tillegg til 97 fotografier og over 3000 gjenstander, leverte Sergel en reiserapport med tittelen «En ekskursjon til de norske samer» etter hjemkomsten til REM i 1908. Rapporten ble først utgitt i 2004, men i 1927 klarte han endelig å utgi boka Et år på reise med samene. Fortellinger om folk og natur, alt sammen skrevet på russisk og stadig vekk ikke oversatt. Intet av dette er dermed lett tilgjengelig i vestlige bibliotek eller for vestlige lesere. Selv ikke den omfattende samiske bibliografien til Lindin og Rydving fra

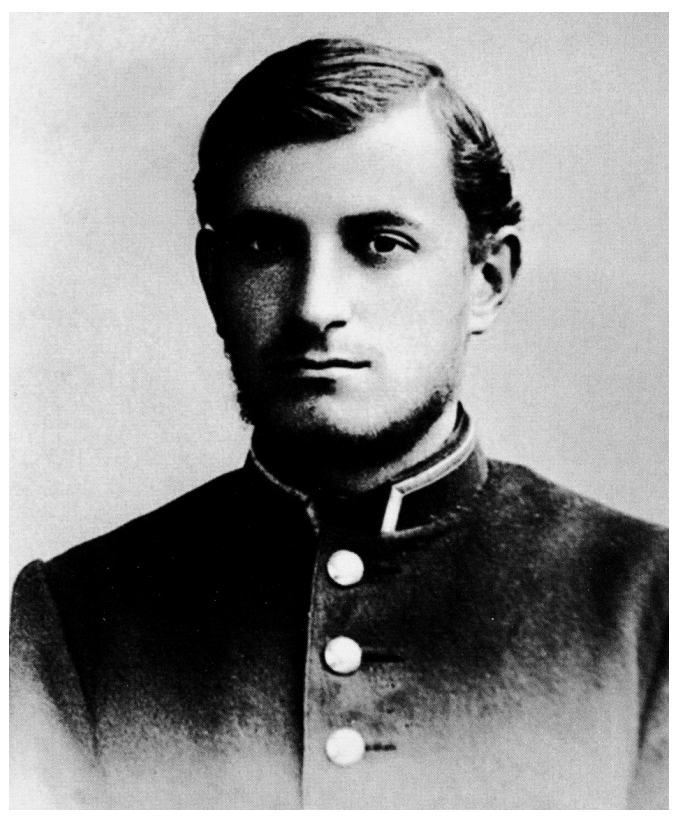

Sergej Sergel (fotografi i REM). 
2007 henviser til Sergels arbeider. I 2012 utga REM et utvalg av hans arbeider, men bare med et par brev og noen fotografier fra hans nordiske reise. Inntil nå har derfor kurator Marina Kuropjatniks artikkel fra 1996 vært den mest tilgjengelige oversikten over Sergels undersøkelser i vesterled. Hun tok for seg både Sergels forskningsmetode, samlinger, fotografier og tekster og karakteriserte ham som en «observant, omtenksom, lærd og human forsker». ${ }^{1}$ Artikkelen er imidlertid fri for kildekritiske kommentarer.

Noe av det samme gjelder Kari Myklebosts sammenligning av Sergels beretning fra norsk Sápmi med Jens A. Friis' forskningsferd blant samene på Kolahalvøya i 1867. Slik komparasjon er i og for seg prisverdig, og vi håper å kunne legge et bedre grunnlag for realistisk komparasjon med andre etnografiske beskrivelser ved å gå kritisk gjennom hans rapport, fotosamling, brev og bok. Slik sammenligning er i seg selv en stor og kompleks forskningsoppgave som faller utenom rammene for vår artikkel. Hos Myklebost blir det et problem at et par misforståelser i Kuropjatniks artikkel gjengis ukritisk. Det gjelder for det ene omfanget av Sergels reise. Muligens har tittelen på rapporten til REM med tidsangivelsen 1907-1908 forledet dem til å tro at han tilbrakte hele året 1908 hos samene og først reiste tilbake til Russland i 1909. ${ }^{2}$ Det ville da være påfallende at han bare skriver om sin deltakelse i reinflyttingen om høsten, ikke om våren. Sergel konstaterer da også selv at han forlot området på ski langs Torneå elv i februar 1908.

Påstanden om at Sergej Sergel var selvlært er også tvilsom. ${ }^{3}$ Riktignok studerte han ved det naturvitenskapelige fakultet, men her fantes en avdeling med flere fremragende geografer og etnografer, for eksempel den berømte etnografen Sergej Rudenko og arkeologen Petr Efimenko. «I 1887 ble det i Fysikk- og matematikkfakultetet i St Petersburgs universitet organisert et in- stitutt for geografi og etnografi. Edward Petri underviste ... i antropologi, ... Fra 1907 ble denne tradisjonen ... videreført av Fyodor Volkov, som så etnografi som en tredelt vitenskap, inkludert fysisk antropologi, etnografi og paleo-etnografi.» ${ }^{4}$ I 1907 fulgte Sergel forelesninger hos Volkov, ${ }^{5}$ som også var del av REMs stab. Den mest berømte fra dette fagmiljøet er imidlertid Nicolaj Miklouho-Maclay (1848-1888), en av antropologiens absolutte pionerer og nestorer som støttet Darwins utviklingslære, men tok avstand fra de rasistiske undertonene om mindreverd. ${ }^{6}$ Dette er relevant for vurderingen av Sergels generelle syn på samene.

Sergel hadde altså akademisk bakgrunn fra Russlands ypperste etnografiske miljø og i tillegg erfaring fra feltarbeid blant komi-syrianere, mansi-nenetsere og de etnisk russiske gammeltroende i det nordlige Ural. Han hadde fătt stipend til disse reisene både fra Institutt for etnografi og REM med bakgrunn i sin utdanning og et anbefalelsesbrev fra universitetsrektor in spe Grimm hvor han hadde vært huslærer. ${ }^{7}$ I samsvar med datidas anbefalinger i etnografifaget praktiserte han feltarbeid over lengre tid med deltakende observasjon som hovedmetode i forskningen. Dels bodde hans fast hos de gruppene han studerte, dels reiste han sammen med dem eller fra gruppe til gruppe. I tillegg til observasjon intervjuet han utvalgte personer, studerte språket, samlet inn gjenstander og målte i noen grad personenes kroppsdeler (antropometri). I likhet med andre kollegaer brukte han fotografier til å dokumentere det etnografiske materialet, og var således med på starten av det som skulle bli visuell antropologi. 97 fotografier ble arkivert i REM etter hans reise i Finnmark og Finland både av landskap, by og miljøer samt portretter. Vi går bare unntaksvis inn på gjenstandsmaterialet han samlet, men henviser til Kuropjatniks oversikt fra 2004. 
En av våre metodiske målsettinger har vært å utnytte fotografiene til noe mer enn illustrasjoner, i samsvar med en renessanse for analyse av slike bilder som etnohistoriske dokumenter. ${ }^{8}$ Især er det viktig å analysere bildene i sin kontekst, både i den generelle historiske sammenhengen og sammen med de tekstene som har samme opprinnelse som fotografiene. Heri ligger en tredobbel målsetting: Å visualisere samisk hverdagsliv ved forrige hundreårsskifte, å illustrere Sergels metodiske feltarbeid, og som støtte til å identifisere de menneskene han møtte og bodde sammen med. Å gjengi alle relevante bilder med analyse fører dessverre for langt.

Når det gjelder identifikasjon, har det norske, nominative kildematerialet vært viktigst. Vi er i den heldige situasjon at Sergel reiste i en periode da kilder som folketellinger og kirkebøker er fullstendige, inneholder mange detaljer, og i stor grad er gjort tilgjengelige ved hjelp av databehandling fordi perioden for klausulering av kildene er utløpt. Især har folketellingene for årene 1900 og 1910 vært til stor hjelp, siden de i sin helhet er transkribert til søkbare formater og vi dermed kunne bruke eliminasjonsmetoden til å identifisere personer hvis navn eller familieforhold Sergel ikke nevnte eller hadde misforstått. Kirkebøkene er i mindre grad transkribert, men når navn, alder, fødested etc. var funnet $\mathrm{i}$ folketellingene hos Registreringssentralen, kunne vi som regel finne dåp og andre vitalhendelser i de skannede kirkebøkene hos Digitalarkivet. Mange aspekter ved Sergels rapport og bok kan med andre ord gis kontekst fra og kontrolleres mot flere uavhengige, samtidige kilder. Selv når navn mangler i Sergels framstilling, kan vi kombinere hans beretning om alders- og familieforhold med hva vi kan tolke ut fra fotografiene og sammenlikne med aktuelle familier i folketellingene. Vi kan så spørre om i hvilken grad han hadde blitt fortalt følsomme forhold i familiehisto- ria, hadde forstått bakgrunnen for konflikter osv. Vårt omfattende personhistoriske materiale legger med andre ord tidsdybde til de få månedene da Sergel utførte sitt feltarbeid.

\section{Forskningsferdens bakgrunn og omfang}

I 1906 til 1907 planla Sergel forgjeves å fortsette sitt feltarbeid blant komi-syrianerne da Etnografisk avdeling i REM fant alternativ finansiering og sendte ham til de samiske områdene vest for Russland. Hvilke prioriteringer i det russiske byråkratiet som bestemte dette har vi ingen sikker kunnskap om, men den som vil kan spekulere om at stormakten av geopolitiske grunner fant det interessant å få førstehånds kjennskap til nærområdene i nord-vest. Oppløsningen av unionen mellom Sverige og Norge hadde skapt et nytt uavhengig naboland. Her holdt flertallet av samene til, en gruppe som et halvt århundre tidligere hadde gjort opprør og hadde etnisk tilknytning til samene på Kola. Det pågikk forhandlinger om rett til fiske for skoltesamene ${ }^{9} \mathrm{i}$ norsk farvann, og et annet tegn på økt interesse for området var flyttingen av en marineavdeling fra Kronstadt til Arkangelsk i 1907. Kong Haakons reise i Finnmark sommeren 1907 var neppe kjent tidlig nok til at det kunne påvirke planleggingen av Sergels ekspedisjon. Men vi kan regne med at bekymringen hos norske myndigheter for at kongens sikkerhet var truet av revolusjonære russere i Kirkenes ble delt i den russiske utenrikstjenesten. ${ }^{10}$

Et tilbakevendende problem for Sergel hvor han enn sto og gikk i Norden, var at de fleste han møtte trodde han var russisk spion. Vi har funnet dokumenter i arkivene både fra det svenske og norske utenriksdepartement som gir tillatelse til reisa, og disse viste han fram for å avvise mistankene. ${ }^{11}$ Svensk UD ba i direkte orde- 


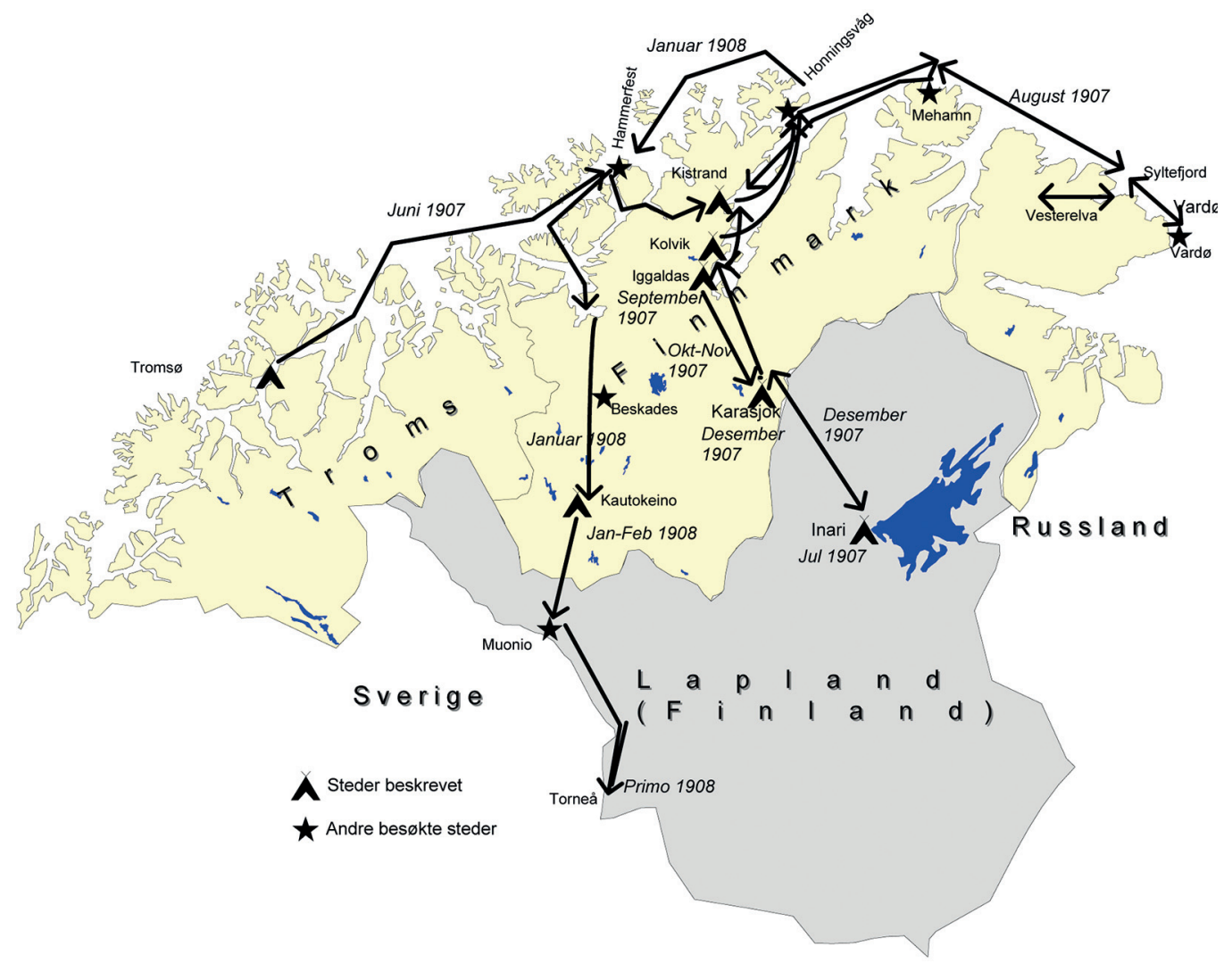

Kart over Sergels reiserute juli 1907 til februar 1908.

lag myndighetene i Norrbotten hjelpe til med å tilbakevise slike beskyldninger. $\mathrm{Vi}$ vil komme tilbake til spørsmålet om det kan være hold i spionmistankene mot Sergel. Vi vet imidlertid at konsul Vizel i Hammerfest hadde rapportert om uroligheter i det nordlige Skandinavia, rykteflom i Finnmark om den russiske fare og mangel på lojalitet blant nordmenn i favør av Russland. ${ }^{12}$ Vizel hadde og som del av sin ordinære virksomhet skrevet et kompendium om skattereglene i byene i nord og hvilke lover som regulerte forholdene for russiske statsborgere som oppholdt seg i Norge. ${ }^{13}$ Vizel var og involvert i forsendelsen av en samling med 104 gjenstander med tilknytning til samene og Boris Gleb til
REM i 1903, og det er ikke det minste merkelig om museet ønsket å komplettere denne vesle samlingen. Beslutningen om å sende Sergel nordvestover kan og ha vært påvirket av at $\mathrm{Vi}^{-}$ zels bror arbeidet i REM.

Kuropjatnik ${ }^{14}$ skriver at Sergel forlot St Petersburg allerede i januar 1907, men vi vet ikke hva hun bygger dette på. I så fall må han ha tilbrakt fire måneder i Finland - Sergel skriver selv innledningsvis at han kom sjøveien til Stockholm i mai. Mappa om Sergel fra svensk UD forteller oss at han tilbrakte de siste dagene i mai og første halvdel av juni i Sverige, mens han ventet på at brevet fra baron F. A. Budberg ved den russiske legasjon skulle resultere $\mathrm{i}$ ak- 
kreditering til å forske i Nord-Sverige. Så tok han toget til Kristiania, men nå hadde han fått det travelt og gikk selv med brevet fra ambassaden til norsk UD. Dette resulterte i rask saksgang, og 19. juni hadde han også norsk akkreditering og kunne sette seg på toget til Bergen. Herfra bar det nordover med hurtigruta, som gledet Sergel ved å stoppe på tallrike steder underveis slik at han kunne observere og fotografere, jfr. bildet fra Hadsel. I Tromsø møtte han for første gang representanter for den samiske befolkning som kom for å selge sine håndarbeider til turistene. ${ }^{15}$ Sergel studerte samlingene i det «fine, lille» Tromsø museum med interesse før han fortsatte reisa til Hammerfest, jfr. kartet over hans reiserute i nord.

Derfra inneholder Sergels bok et avsnitt om en omreisende agitator fra det sosialdemokratiske partiet som talte til en forsamling med 20 til 30 arbeidere; imot alkoholisme og urettferdige skatter og i favør av 1. mai-feiring. ${ }^{16}$ Han møtte og en revolusjonær russer som angivelig hadde flyttet fra Kiev til Norge etter revolusjonen i 1905 og var sendt til Hammerfest av sin politiske gruppering for å propagandere blant pomorene. ${ }^{17}$ Møtene med de radikale nevnes ikke med ett ord i rapporten til REM fra 1908 da det kunne innebære problemer for de omtalte personene. $\mathrm{Ti}$ år etter revolusjonen derimot, var slikt noe som ikke bare skapte interesse, men som kunne påvirke utgivelse av boka i positiv retning. På side $11 \mathrm{i}$ boka gjengis et fotografi av byen og havna med den enkle tittelen «Hammerfest». Kunstneren Sergel møtte kan ha vært V. A. Plotnikov som tilbrakte deler av 1907 og 1909 blant samene, samlet gjenstander og malte bilder for REM. ${ }^{18}$

Fra Hammerfest dro Sergel videre østover med dampskip, først via Neverfjord hvor en fisker rodde ham til Repparfjord. Herfra fortsatte han de ca 80 kilometerne til Kistrand til fots.
Han leide et ubebodd hus av den lokale kjøpmann «Nilsen» - vi kommer tilbake til hvorfor en slik person ikke lar seg finne i folketellingene. Kjøpmannens sønn vakte betydelig interesse, en «meget sterk ung mann» som snakket brukbart russisk. Det dreier seg sannsynligvis om språkferdighet godt over russenorsk-nivå; på grunn av den utstrakte handelen med pomorene var det vanlig å sende ungdom østover på språkopplæring som del av praktisk utdannelse, på samme måte som russere lærte seg norsk under opphold i Troms og Finnmark. ${ }^{19}$ Familien var i realiteten enda mer internasjonal. Grunnen til at Sergel ikke møtte sønnen Martin var hans fravær som jordbruksarbeider i Minnesota fra 1905 til $1910 .^{20}$

De lokale russiskkyndige var til stor hjelp for Sergel i hans studier av den sjøsamiske befolkninga. Ved å kjøpe mat og gjenstander ble han kjent med mange og fikk detaljerte opplysninger om levesett, språk, etnisk sammensetning og etnisk inngifte som samsvarer med annet kildemateriale: Både kvener og $\mathrm{i}$ noen grad norske giftet seg med samiske kvinner, men sjeldnere med samiske menn. Mange samer og kvener snakket og forsto hverandres språk, samenes norskkunnskaper var noe bedre enn kvenenes, mens nordmenn sjelden behersket samisk eller finsk. ${ }^{21}$

\section{Sjøsamiske brødre: Fattig og rik}

I kjøpmannens butikk møtte Sergel en same som var på vei hjem etter utbytterikt fiske, og gjorde avtale om å bli med til hans hjem i nærheten av Kolvik. Med i båten var og en av de samene som hadde introdusert reinsdyrhold blant inuittene i Alaska på 1890-tallet. Dette kan ha vært Anders Klemet Biti fra Karasjok, som sammen med kona Marit Nilsdatter var reinvoktere i Alaska fra 1898 til 1900 og fikk en 
Landskapsbilde som Sergel tok på vei nordover. Hanøy $\mathrm{i}$ Hadsel i retning Ingelsfjord. $\mathrm{Vi}$ takker Johan Borgos for hjelp til å identifisere stedet. (Sergel 1927 side 8).

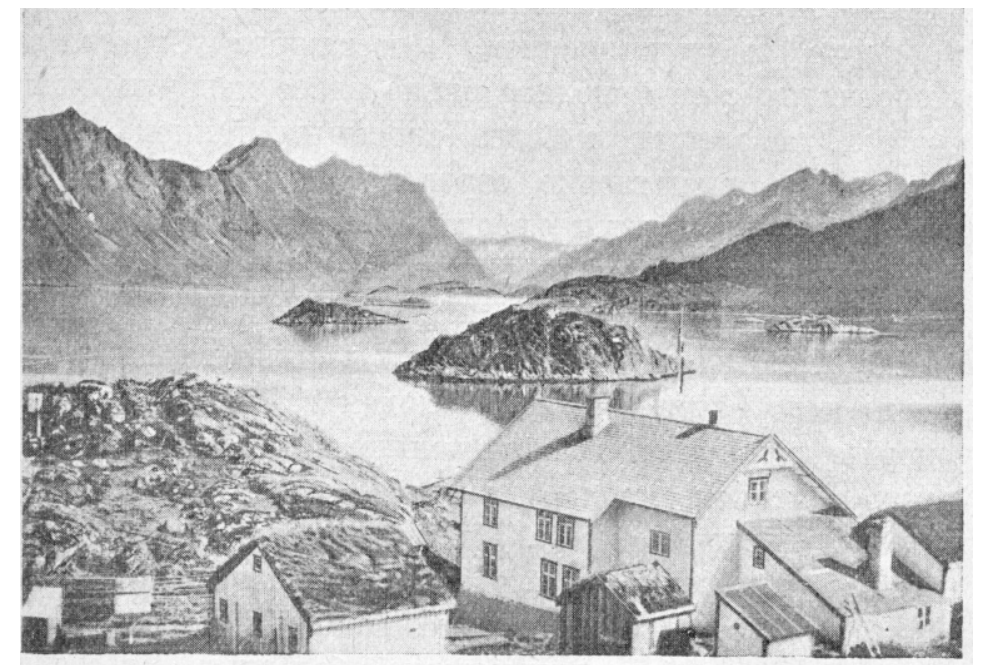

sønn der. ${ }^{22}$ Stedet Sergel nå kom til lå et lite stykke fra fjorden, og han mente alle innbyggerne der var i slekt. I sjøsamens hjem tok Sergel et bilde med tittelen «Familien til en velstående sjøsame. På hyllene trekar med melk», gjengitt i hans bok fra 1927. Dessverre fulgte Sergel skikken blant etnografer i denne perioden og utelot navn på familiemedlemmene, slik at de fleste personer de fotograferte forblir anonyme. Heldigvis kom han lenger ut i boka tilbake til denne familien og navngir da Per Larsen fra Iggaldas som han besøkte sommeren 1907. Ved hjelp av folketellingene 1900 og 1910 lar det seg gjøre å knytte sammen disse avsnittene i Sergels beretning. Der finner vi naboene Per og Anders Larsen, som må være de to brødrene Sergel besøkte ca syv kilometer sør for Kolvik. Per og kona Rakel Rasmusdatter hadde to døtre som var ca 20 år i 1907 og den yngre sønnen Anthon Helmer, og det er bra samsvar mellom beretning, fotografi og folketellinger. 1910-tellinga oppgir grunnlaget for familiens velstand i og med Pers yrkestittel: Fiske, gårdsdrift og handel.

Hos Sergel finner vi nærmere beskrivelse av det viktigste produksjonsmidlet: En «barkas»- dvs. en enmastet seilsjekte med overdekket kahytt og rikelig med fiskeredskaper. Per Larsen hadde solgt fisk i Kistrand og brakte derfra sekker med mel og tørkede fiskehoder - sistnevnte ble brukt som fôr. 1907 var et godt år, hjemkomsten skjedde med relativ rikdom - både penger, mel, andre forsyninger og presanger og de kunne se vinteren lyst i møte. Om det ikke hadde vært for Rakels kløkt kunne velstanden og ha brakt problemer. Dagen etter hjemkomsten hadde Per invitert hjem en reingjeter for å smake på «norsk rom». Rakel «lot ham kose seg en passelig stund med rom og lyden av penger, men etter hvert fikk hun hånd om både flaska og pengene». Døtrene Anne Kristine og Marie Elise bidro også til husholdningen, for eksempel med brødbaking. Deigen ble laget i et trekar, så rullet til en flat leiv $1 / 3$ meter i omkrets og stekt direkte på den varme ovnen, brødet ble stadig snudd for å unngå at det ble brent. De serverte det ferske brødet med smør og melk. ${ }^{23}$

Dette året forhyrte Per to samer som hjalp til med fisket, se fotografiet av de to fiskerne. Sergel beskriver levende den seilasen han deltok i sammen med dem: «... mens den eldre sto til 
rors, slo den yngste seg ned på sekkene og sang den ene sangen etter den andre. Etter en stund erstattet han eldstemann ved roret og stemte i en melankolsk, norsk sang. Den eldste arbeideren stemte $i, o g$ deres vennlige og vakre sang varmet oss på den kalde dagen». ${ }^{24}$ Dessverre har vi for lite opplysninger til at de to lar seg identifisere.

Fortjenesten var investert i et godt toetasjes hus med svalgang, noe som ikke var helt vanlig $i$ dette distriktet på grunn av mangelen på bygningsmaterialer. Sergel beskrev huset ganske inngående: Det hadde fire rom, to i hver etasje, hvert rom oppvarmet med en liten jernovn. Da han tok familiebildet, hadde de brakt bord og stoler inn i hovedrommet for anledningen. Ellers var det soverom med høymadrasser på gulvet og en vugge til den nyfødte - Lars Sivert var født 6. august 1907 ifølge 1910-tellinga. De andre syv barna sov i de to rommene ovenpå, også utstyrt med høymadrasser og reinsdyrfeller på gulvet - i Kistrand var det ifølge Sergel vanlig med senger. Det andre rommet nede ble brukt som kjøkken. Man gikk inn i kjøkkenet via svalgangen og så fra kjøkkenet enten til hovedrommet nede eller direkte ovenpå. Familien rådde og over et hus til forrådskammer med klær, tørrfisk og reinkjøtt, ett skjul til kuene og ett til ved. I tillegg hadde de en stabburslignende konstruksjon til å tørke fisk og høy en mannshøyde over bakken.

Den velstanden Sergel beskrev hos Per står i kontrast til fattigdommen hos broren Anders Larsen. Han var tre-fire år yngre, født i 1867. Kona Berit Nilsdatter var tynn, blek og så sliten ut da Sergel kom inn i huset - grunnen var åpenbar - hun hadde en komse med en nyfødt baby på fanget. Husets eldste kvinne, Kirsten, som Sergel trodde var Anders' mor, derimot, ga et helt annet inntrykk. Da hun hørte at Sergel var interessert i samiske tradisjoner, spratt hun opp og snakket i vei, men i likhet med Anders behersket hun kun samisk. Snart gikk hun over til «tegnspråk» for å demonstrere sine helbredelsesmetoder basert på naturmedisin. Ved hjerteproblemer skulle man drikke ferskt reinsdyrblod, smerter etter slag mot kroppen skulle lindres ved å brenne chaga ved den aktuelle kroppsdelen, og så smøre på salve blandet med asken. ${ }^{25}$ Kirsten utøvde sine kunster på Anders som av den grunn hadde mistet håret ved øret. Hun bedrev og årelating for å lindre og forebyg-

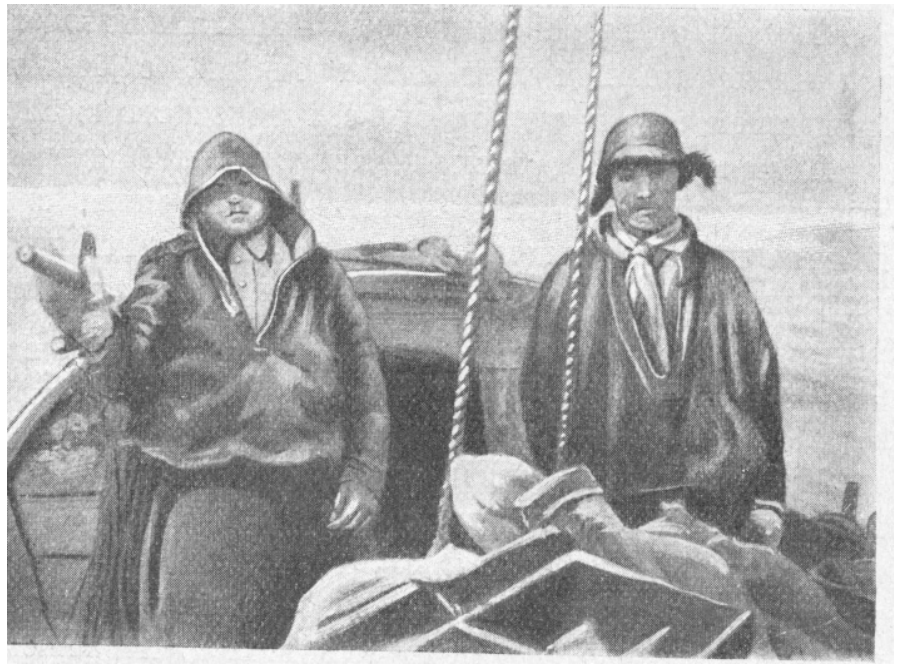

Fiskere ansatt hos Per Larsen, Iggaldas. (Sergel 1927 side 33). 
ge lidelser. Ytterligere en preventiv metode var å vikle bandasjer laget av reinsdyrsener omkring håndleddet som forberedelse til hardt arbeid. Sergel beklaget at språkvansker forhindret ham i å lære mer av den eldre, aktive og oppegående kvinnen.

Hans naturmedisinske fortolkning virker allikevel tilforlatelig, men han misforsto om slektskapet. Anders og Pers mor døde ifølge kirkebo$\mathrm{ka}$ av tuberkulose i 1904. Ifølge folketellingene både i 1900 og 1910 bodde en annen eldre kvinne, Kirsten Samuelsdatter født i 1840 hos Anders og Berit, trolig gjennom hele tiåret. Hun var antagelig et fjernere familiemedlem som bodde der på legd, en institusjon Sergel for øvrig beskrev i sin rapport til REM. ${ }^{26}$ Kirsten bød Sergel på kaffe kokt på husets åpne peis med pipeløp bygget av stein - mangelen på jernovn var tegn på fattigdom. Boka fra 1927 inneholder et bilde av en åpen peis med kaffekjele, antagelig den Kirsten serverte Sergel kaffe fra under besøket hos den fattige, men gjestfrie familien i Iggaldas. Han besøkte og et lite tettsted nær ved med fem små hus hvor det bodde noen «svært fattige» samer. I et par av husholdene observerte han ekstrem nød, sykdom og fattigdom. Han mente dette var tidligere reindriftssamer som hadde mistet sine flokker og måtte bosette seg ved kysten og bli fiskere. ${ }^{27}$

Rapporten og boka gir ingen fullstendig beskrivelse av Sergels observasjoner og aktiviteter. I i et brev skrevet i september til veilederen, Fedor Volkov, fortalte han om en utflukt til sjøsamene i Stabbursnes hvor han kjøpte en «vertikal» vevstol av en type som ikke lenger var i bruk blant samene. Han var stolt over å ha fått tak i et mer velholdt eksemplar enn det han hadde sett $i$ Tromsø museum. ${ }^{28}$ I rapporten beskrev han vevstolen og hvordan den skal brukes. ${ }^{29}$ Fra Iggaldas ble han rodd av en gruppe samer til Kolvik hvor han overnattet i et skur hos en stor og fattig familie sammen med noen tønner som luktet sterkt av fisk. Sergel var imponert over geografikunnskapene til den tiårige sønnen i familien som hadde utstrakte kunnskaper om Russlands natur, byer og revolusjonære begivenheter. I denne sammenhengen nevner han lærer, kirkesanger og avisutgiver Isak Saba som inspirator. Saba satt som første same på Stortinget fra 1906 til 1912 - for sosialdemokratene. Sergel fikk dampskipsleilighet til Kistrand hvor han igjen tok inn hos kjøpmann «Nilsen».

\section{Varanger og retur til Porsanger}

En viktig målsetting for Sergel var å observere variasjonsrikdommen i de etniske kulturene han studerte. Han mente noe upresist å kunne skille mellom tre grupper reindriftssamer: En gruppe som ambulerte med lavvo («koakhty») i det vestlige og sentrale Finnmark, en som hadde vinterkvarter på Finnmarksvidda med sentra i Karasjok og Kautokeino, og en som tilbrakte vintrene i Sør-Varanger og somrene på Varangerhalvøyas nordkyst. Det er på denne bakgrunnen vi må forstå hans avgjørelse om å inkludere også Øst-Finnmark i ekspedisjonen. Via Honningsvåg reiste han med dampskip til Vardø, hvor han i slutten av august tok inn på hotell vel den eneste anledningen han ikke benyttet til å overnatte privat. Der besøkte han trykkeriet til byens sosialdemokratiske avis, Finnmarken. Her møtte han en nok en radikal russer som hadde stukket av fra eksil i Arkangelsk og bisto med trykkingen av revolusjonære skrifter på russisk, blant annet avisa Pomor som ble spredd blant og via de pomorene som besøkte Vardø. Den unge russiske sosialisten mente mange av pomorene var politisk konservative, det gjaldt især de mest velstående. ${ }^{30}$

Sommeren gikk mot slutten, og Sergel startet planleggingen av vinterens opphold hos rein- 
driftssamene. For å se rein på beite i Varanger tok han dampskip nordover til Syltefjord hvor han igjen overnattet hos samene. De bodde i gammer som var inndelt i flere rom, noen til folk, andre til fe. Sergel var fascinert av en historie han hadde hørt i Porsanger om et par-tre familier som livnærte seg av reinnomadisme i de indre delene av Varangerhalvøya. Dette ville han observere, og bega seg på fottur vestover langs Vesterelven. Under anstrengelsene hallusinerte han om lyden av reinsdyrbjeller og synet av telt og mennesker langs horisonten, men måtte gang på gang slå fast at stedet var øde. Vi vet ikke om så var tilfellet - folketellingene ble avholdt i desember, og de angivelige reindriftssamene kan ha hatt andre vinterkvarter. Med blodige føtter på grunn av det vanskelige terrenget måtte han etter noen dager konstatere at turen var forgjeves og gjøre vendereis. Det eneste resultatet var et bilde med tittelen «Indre deler av Varangerhalvøya». ${ }^{31}$ I Syltefjord var han rekonvalesent hos en gårdbrukerfamilie som forberedte emigrasjon til Amerika. Med dampskip returnerte han via Mehamn til Kistrand.

Tragiske omstendigheter giør det endelig mulig å identifisere kjøpmann «Nilsen» som han igjen tok inn hos. Sergel skrev at «gamle Nilsens sønn nylig druknet da han krysset fjorden i stormfullt vær». ${ }^{32}$ Kirkeboka for Kistrand har denne innførselen om drukningsulykken 25. august 1907: «Ingvald Lillebo, kjøpmann, ugift», født i 1872, hadde forulykket sammen med en ansatt «Samuel Josefsen, fisker, gift», født i 1872. Sergel tok tydeligvis feil med hensyn til seniorkjøpmannens etternavn og patronym. John (Johnsen) Lillebo fra Røros hadde vært kjøpmann i Kistrand fra før 1875 og var gift med kven Marie Marlene Abrahamsdatter, født i 1842/43 i Muonioniska. Nå hadde kjøpmannsfamilien mistet eldste arving og hadde ikke engang noen å begrave. Ikke så underlig at
Sergel hørte morens gråt bakom veggen om natta. Det var enda godt at andre barn sto klare til å overta, Eldstesøster Bolette bestyrte telegrafen allerede, ifølge 1900-tellinga. I 1910-tellinga var nest eldste sønn Alfred fylt tretti år og hadde overtatt som kjøpmann mens senior John står som betjent.

Med september mente Sergel at hans studier blant sjøsamene var fullført. Han pakket og sendte over 150 gjenstander til REM og skrev på sin rapport. Der ga han uttrykk for et positivt syn på samene til tross for vansker med å finne noen som ville ta ham med på høstvandringen innover vidda. Som Kuropjatnik skriver ville ikke Mattis Andersen ha ham med fordi kompanjongen angivelig var redd for at Sergels onde øye kunne påvirke reinen. ${ }^{33}$ Igjen seilte Sergel fra Kistrand til Iggaldas med Per Larsen. Medpassasjer var Henrik Andersen Sara, en reineier på vei mot Karasjok som Sergel skulle bli godt kjent med.

\section{Familien Sara og Karasjok}

Vi vet at Sergel betalte Per Larsen for å arrangere reinsdyrfølge til vinterbeitene, men ikke om Henrik i noen grad klarerte avtalen om å la Sergel bli med familien til reinbeitene ved Karasjok med sine brødre Aslak og Mikkel eller sin mor Marit. Som yngste sønn hadde han arverett til reinflokken ifølge samisk sedvane om ultimogenitur ${ }^{34}$ og kunne ta slike avgjørelser - om hans autoritet enn var omstridt. Sergel følte nok at familien ga ham en noe reservert mottakelse, men etter overrekkelsen av gaver var isen brutt. Karasjok var imidlertid ikke det tradisjonelle territoriet for denne delen av Sara-familien. De tre brødrene (og deres søster) var alle født i Kautokeino, ifølge kirkebøkene i henholdsvis 1855 , 1866 og 1878. Det var etter at faren døde i 1888 at de flyttet østover. Noe av bakgrunnen må 
være nedbeitingen av områdene ved Kautokeino etter stengingen av grensene for reinvandring $\mathrm{i}$ 1852, og kanskje at familien hadde vært aktiv i Kautokeinoopprøret. Sergels beskrivelse av dagliglivet ble nå mer detaljert fordi hans kunnskaper i samisk ble bedre. «... i starten var [han] stille under vertsfamiliens samtaler, men litt etter litt lærte [han] å forstå dem og endog delta i samtalene ... [noe som] hjalp til med å klargjøre deres karaktertrekk og relasjoner». ${ }^{35}$ Selv om hans observasjonsevne ble bedre, manglet han innsikt i familiens historiske bakgrunn både på grunn av spinkle språkkunnskaper og fordi hans vertskap silte informasjonen.

Dette er mest slående med hensyn til Kautokeinoopprøret i 1852 som Sergel nevner i sin rapport til REM, men der er ikke ett ord om Sara-familiens tilknytning til drapene på lensmannen og handelsmannen. ${ }^{36}$ Moren til de tre brødrene, Marit Aslaksdatter Skum (født 1835), var søster til Ellen (født 1827) hvis flukt i flere framstillinger er gjort til hovedfaktor i opprørets innledningsfase. Hennes dødsstraff ble omgjort til livsvarig fengsel, men hun ble løslatt i $1867 .{ }^{37}$ Brødrenes onkel ble og benådet, men døde i fengselet, mens mormora satt inne til 1864. Dette rammet familien hardt både økonomisk og moralsk. Voktingen av reinen ble vanskelig når så mange satt i fengsel, og det var heller ikke greit å være stemplet som en av «morder-familiene». Sergel skriver at Sara-familien ikke var spesielt velkomne blant dem som tradisjonelt hadde reinbeiter ved Karasjok etter at de hadde flyttet østover. ${ }^{38} \mathrm{Vi}$ mener den mest sannsynlige forklaringen er at Sara-familien unnlot å nevne den skambelagte tilknytningen til opprøret, og at Sergel hadde liten grunn til å utelate dette poenget i en russiskspråklig framstilling.

Da Marit ble enke i 1888, var yngstegutt Henrik bare ti år og kunne selvsagt ikke overta kommandoen over reinflokken, som ikke var spesielt stor - selv om 250 dyr ifølge folketellinga 1875 godt kan være et for lavt satt tall. Hun hadde ikke giftet seg på nytt og fungerte åpenbart som familiens overhode mens Henrik var tenåring. I 1907 var han blitt voksen og i ferd med å overta kontrollen i stadig større grad, noe som skapte konflikter mellom mor og sønn. Sergel la gang på gang merke til hvordan han diskriminerte mor Marit når han fordelte mat og godsaker - hun måtte med et sukk konstatere at det ble ingen sukkerbit på henne. ${ }^{39}$ Det er og mulig å fortolke folketellingene slik at de gjenspeiler konflikten. I 1900 ble Henrik ført som tjener og reinsdyrgjeter i husholdet til søster Kirsten, født 1861. Men han ble også ført som midlertidig fraværende i morens hushold, ${ }^{40}$ en oppføring som siden ble strøket. Dette kan tol-

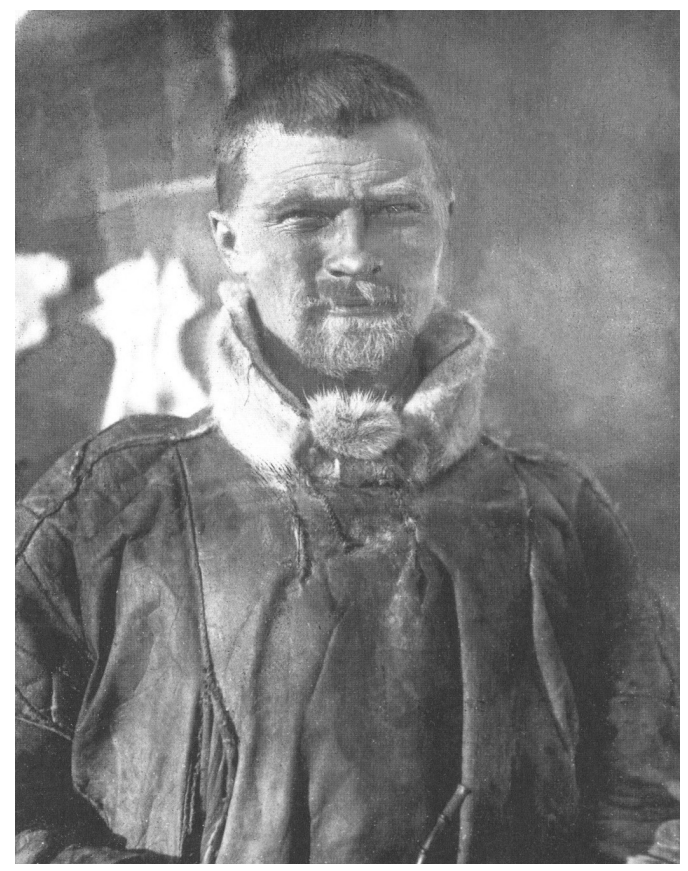

Henrik Andersen Sara en face. Yngste $s ø n n$ og eslet til å være overhode for denne delen av Sarafamilien (Sergel 1927 side 168). 
kes slik at Marit hadde plassert yngste sønn hos datter og svigersønn for å beholde kommandoen; Henrik ba folketelleren føre ham inn i morens hushold, mens moren ba innførselen strøket. I 1907 hadde han ifølge Sergels beskrivelse lykkes i å overta føringen:

han var nesten middels hoy, holdt kroppen rak med en anelse arroganse. Han hadde et avlangt varbarket ansikt med et lyst, kort skjegg, hans skarpsindige blikk var fast. Det uttrykte rolig uavbengighet. Henrik er yngste bror, men senior $i$ status. Brodrene liker ham tydeligvis ikke, de er fryktsomme og underordnede. Hvordan fikk han det til? Han snakket ikke mye, ropte aldri med boy stemme. Men han innga respekt med sine rolige bevegelser, skarpe blikk og bare stillhet. ${ }^{41}$

Morens status som husholdsoverhode i 1910 kan være en formalitet, men det kan og tyde på at konflikten ennå pågikk. Alt tyder på at Henrik forble ugift. Han hadde i noen tid hatt Kristina (noen steder kalt Kirsten) som tjenestejente, men ville ikke gifte seg med henne - hun var 16 år eldre. Ifølge Sergel var løsningen å gifte henne bort til bror Aslak for å ikke miste hennes verdifulle arbeidskraft. Sergels bok inneholder bilder av henne etter datidas etnografiske oppskrift: En face og i profil, samt følgende beskrivelse av en idealkvinne: «... en snill og sky kvinne, veldig øm overfor sine og Aslaks fire barn og forsøker alltid å arbeide nær dem. Hun gir dem alt de trenger, klær, mat, ly, omsorg og ... kjærlighet, ellers lar hun dem lære av naturen og livet». Beskrivelsen av barna er også positiv: De er «skjønne og attraktive», enten det gjelder den godhjertede åtteåringen Maret, den pene seksåringen Karen med den vakre stemmen, den entusiastiske fireåringen Lemik og den lille godhjertede og lett kokette Anna. ${ }^{42}$
Sergel hadde like mye til overs for gamlemor Marit, en gang familiens overhode. Hun tok sin tørn med reingjetingen selv om hun hadde passert de sytti. For å holde tyver og ulver unna og holde flokken samlet krevdes konstant vakthold, til vanlig ved mennene om dagen og kvinnene om natta, ifølge Sergels rapport. Om morgenen ville hun bringe flokken til leiren for å spise og få avløsning. Jobben var ekstra stri i dårlig vær, Sergel gjengir en historie om at 150 dyr gikk utfor et stup i snøstorm og at den kvinnelige gjeteren frøs i hjel. Det ville være interessant å kontrollere hans beretning om at kvinnene kunne føde mens de forble på sin post mot andre kilder. ${ }^{43} \mathrm{Vi}$ mener å ha identifisert Marit Aslaksdatter Skum på et av Sergels bilder, gjengitt her. Dette er så vidt vi kan konstatere det eneste bilde som fins av noe kvinnelig medlem i de familiene som spilte en hovedrolle i Kautokeinoopprøret.

Mikkel var Marits eldste sønn (født i 1855) og hovedperson i den andre lavvoen hvor han bodde sammen med kone Inka (Inger Marie) født i 1878 og hennes søster Nelli (Elen Marie) født i 1883 ifølge dåpslistene for Kistrand prestegjeld. De kom fra enkle kår, foreldrene var fiskerbønder med ei ku og ti får ifølge 1875-tellinga, men begge hadde fullført skolegang. Sergel beskriver det vanskelige ekteskapet mellom Mikkel og Inka:

[han] hadde arvet sin mors godhjertethet og en skyhet som var blandet med tristesse. Melankolien hadde åpenbart rot i forboldet til kona. ... hun hadde et ganske ordinart samisk ansikt, men når hun var oppromt og smilte var bun vakker. Hennes gråblå oyne lyste omt, ansiktet uttrykte godhet og sky flort. Mikkel elsket Inka, men forsto at han ut fra alder kunne vart hennes far. Hun ektet ham fordi hun var tiltrukket av et rikere liv og uavhengighet. Mikkel var 
tiltrukket av Inka og forventet respons og kjartegn, men ble bare mott med iskald kulde. Så fant han trost $i$ a lese Bibelen. Stakkars Mikkel leste den gamle boka boyt med dyp innlevelse og båpet å finne belsebot for sine sår. ${ }^{44}$

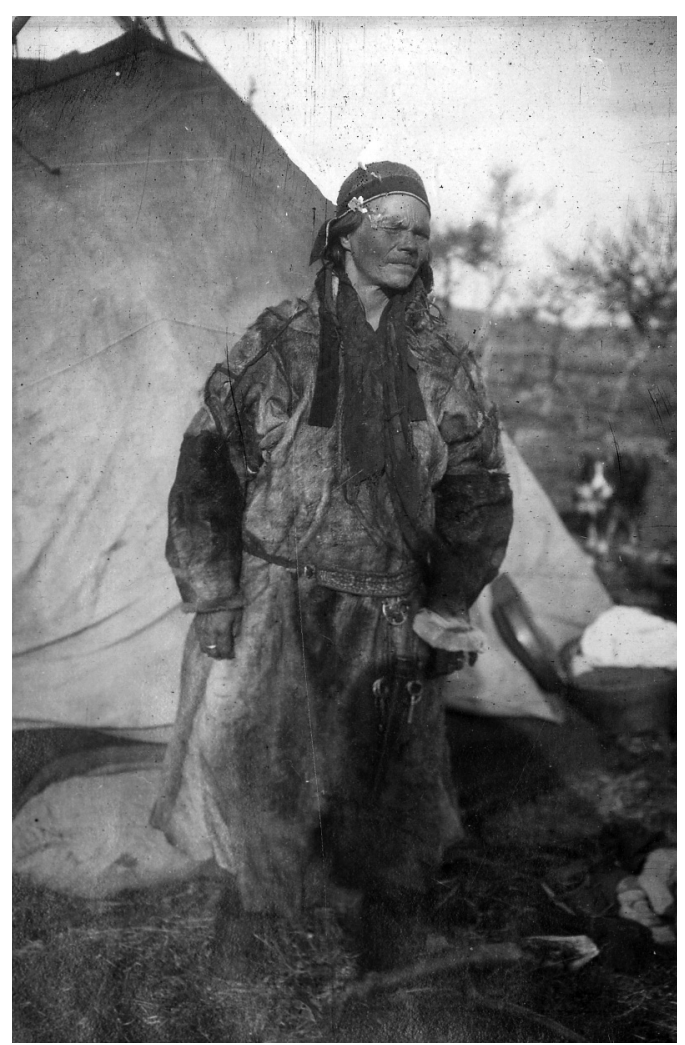

Marit Aslaksdatter Skum. «... Hun holdt kroppen rak med hodet lett tilbakelent og rank som en kommanderende høvding foran troppene. Ansiktstrekkene er alvorlige og skarpe som hos en indianerkriger som ser tappert rett fram. Bak alt dette er der imidlertid en verdensvis godhjertethet og en filosofisk, edel holdning. ... [Når hun gjette rein] lød stemmen ikke svakere enn hennes barns stemmer. Hennes fløyelsmyke stemme var sterk og klar når hun snakket til familiemedlemmene.» (Sergel 1927 side 97).
Sergel gjengir og Marits beskrivelse av Mikkels deltakelse i en gruppe samer som reiste mellom europeiske storbyer for å vise fram reinsdyr og samisk etnografi, det hele angivelig iscenesatt av en engelsk agent. ${ }^{45}$ Dette kan forklare at han hadde oppnådd en viss økonomisk uavhengighet, selv som eldre sønn i en familie som tidlig mistet $\sin$ far og forlot sine tradisjonelle reinbeiter. Vi kan anta at økonomi og var bakgrunn for hans muligens arrangerte ekteskap. Sergel skriver at (arrangerte) ekteskap av økonomiske grunner var vanlig mellom sjøsamiske kvinner og menn med reinsdyrflokker. ${ }^{46}$ Som vi forstår kunne dette være lite vellykket. Ifølge genealogiboka for Karasjok døde både Mikkel og Henrik barnløse eller langvarige misforhold til de viktigste kvinnene i sine liv. ${ }^{47}$ Familiens deltakelse $\mathrm{i}$ den omreisende truppen bekreftes $\mathrm{i}$ Cathrine Baglos avhandling På ville veger? fra 2011 - både Mikkel og søsken figurerer på foto som er tilgjengelige $\mathrm{i}$ avhandlinga via Internett. ${ }^{48}$ Det dreier seg om den tyske agent $\mathrm{Ha}$ genbecks andre samiske ekskursjon i 1878-79. At Sergel ble med nettopp Sara-familien til vinterbeitene var altså ikke tilfeldig, de var vant til å omgås utlendinger og var vel og mer språkmektige enn gjennomsnittet.

Midt i desember 1907 bestemte Sergel seg for å reise til Karasjok. Ved avskjeden med familien Sara var stemningen god, og alle, barna inklusive, utvekslet gaver med den russiske gjesten. ${ }^{49}$ Henrik brakte ham til tettstedet i løpet av tre døgn, på veien overnattet de i statens fjellstuer. I Karasjok tok Sergel inn hos den fastboende Johann(es) Persen Guttorm, reinsdyreier, postmann og framtredende læstadianer. I tillegg til studier av lokal samisk økonomi, kultur, levevis og kjønnsdelt arbeid, fikk Sergel en grundig innføring i Læstadius' lære. Det skjedde ikke minst gjennom en avstikker sammen med Persen til de religiøse julemøtene i finsk Enare hvor 
Sergel fikk anledning til å vise sine empatiske evner da han foretok datatidas foreskrevne antropometriske målinger. ${ }^{50}$

\section{Retur via Kautokeino}

Et studium av samene i Finnmark kunne vanskelig fullbyrdes uten et besøk i Kautokeino, og Sergel bestemte seg igjen for å reise via Porsanger. Med hest og slede ble han brakt til Kolvik hvor han overnattet tre døgn hos en ny kjøpmannsfamilie. Igjen misforsto han vertsfamiliens sammensetning. Ingen annen enn kjøpmann, poståpner og dampskipsfører Bernt Anton Bye født 1853 i Levanger og hans hushold stemmer overens med beskrivelsen, bortsett fra at Bye ikke var enkemann - kona var vel fraværende av andre grunner. Her dominerte norsk etnisk kultur, og døtrene underholdt sin gjest med pianomusikk av Grieg og norske sanger. Dampskipet tok Sergel via Honningsvåg og Hammerfest til Altafjorden hvorfra en karavane med reinsdyr og gjetere førte ham til Kautokeino i løpet av fire dager. ${ }^{51}$

Sergels beskrivelse av Kautokeino og innbyggerne deromkring er mindre positiv enn av de tidligere omtalte stedene. Især framhevet han utstrakt fyll. ${ }^{52}$ Han er imidlertid rosende overfor de samiske skolebarna som så godt ut, var pent kledd, sunne og friske bortsett fra et par som han mente var preget av hjemlengsel. Skolematen besto av reinkjøttsuppe og brød. Han intervjuet en lærer som fortalte at barna i de to første årene $\mathrm{i}$ hovedsak ble undervist på samisk, men deretter på norsk. Det fantes lærebøker med parallelle tekster. Fornorskingspolitikken gjør han oppmerksom på andre steder, men overfor elevene omtaler Sergel den ikke, en hard nasjonaliseringslinje overfor etniske minoriteter kan da heller ikke ha overrasket en russer. Den unge læreren uttrykte allmenn tilfredshet med sine elever. ${ }^{53}$
I slutten av januar 1908 bestemte Sergel seg for å vende tilbake til Russland. En reingjeter brakte ham til Muonioniska, og så gikk han på ski de ca 300 kilometerne til Torneå. Dette tok et par uker, for han gjorde sin vane tro mange avstikkere underveis. Hans reisekasse var allerede disponert, så han måtte kansellere sine planlagte ekskursjoner blant samene i Sverige og Sør-Norge. Med tog gjennom Finland var han snart tilbake i REM i St Petersburg med 317 gjenstander, 10 tegninger og 97 fotografier.

\section{Oppsummering og vurderinger}

Det avanserte etnografiske miljøet i St Petersburg sendte den viderekomne etnografistudenten Sergej Sergel til Skandinavia og Finland for å studere samisk kultur og samle gjenstandsmateriale. På grunn av mangel på ressurser varte ekskursjonen blant samene bare et drøyt halvår, og han måtte konsentrere seg om sjøsamene $\mathrm{i}$ Finnmark og reindriftsnomadene der og i Finland. Ved å jevnføre hans beretning og bok med samtidig kildemateriale - især nominative kilder - har det latt seg gjøre å identifisere mange av de personene Sergel møtte, beskrev og fotograferte, og gi kontekst ut over kontakten gjennom de få ukene da Sergel ble kjent med dem. Konklusjonen på vår kildekritikk er at innholdet i hans rapport og bok i hovedsak støttes av annet kildemateriale, men at han tok feil med hensyn til enkelte detaljer som navn og familierelasjoner. Vi vil ikke legge vekt på at hans bok kom ut to tiår etter at ekskursjonen ble gjennomført, dette skyldtes problemer med å få utgitt et ferdig manus $i$ et land under omveltning.

Hovedproblemet er imidlertid at han i løpet av et feltarbeid på ca. et halvt år ikke var i stand til å sette seg skikkelig inn i livshistorien til de samiske familiene han møtte. Han fikk for eksempel med seg Sara-familiens deltakelse i le- 
vende utstillinger av samisk etnografi på kontinentet, men ikke deres nære tilknytning til Kautokeinoopprøret. Her spilte nok også språkproblemer en rolle. På kysten hadde han hjelp av lokale russiskkyndige personer. Hvis Kuropjatnik har rett $\mathrm{i}$ at han oppholdt seg de første månedene av 1907 i Finland, burde han ha lært seg en del finsk, men så ser ikke ut til å ha vært tilfellet. Noe norsk behersket han antagelig, men vi vet ikke hvor mye. Det samme gjelder de kunnskapene i samisk som han praktiserte sammen med familien Sara, men han innrømmer at intervjuene ble vanskeliggjort av språkproblemer. Mens vi kan stole på hans gjengivelse av observasjoner og hovedinnholdet $\mathrm{i}$ hva han ble fortalt, må vi stille oss skeptisk til detaljene.

Vi stiller oss også skeptiske til diverse omtaler av Sergel både i samtida og fra forskerhold. Selv om hans oppdragsgivere kan ha hatt interesse av opplysninger av en type som kan kalles spionasje, er det ingenting som tyder på at Sergel hadde slike hensikter - tvert imot utelot han notater om russiske revolusjonære i rapporten til REM. Vi er her på linje med svensk og norsk utenrikstjeneste som tillot forskningsferden, og førstnevnte ba altså lokale myndigheter dempe slike mistanker. Selv om omfanget måtte reduseres, gjennomførte da og Sergel et fullstendig etnografisk feltarbeid med rapport, innsamling av mange gjenstander, en rekke fotografier og skisser, samt til sist en bok.

Myklebost har i utgangspunktet rett $i$ at han «tok bilder der han brukte [teknikken] med strengt antropologiske portretter». ${ }^{54}$ Men også dette må settes inn i sin kontekst, og det dreier seg om to til tre av 97 fotografier - profilportrettene av Henrik og Kristina og eventuelt av Marit i helfigur. En face-bildet av Kristina som pryder forsiden på REMs utgave av Sergel i utvalg fra 2012, vil vi i og for seg karakterisere som et flott portrett, og på bakgrunn av hans positive omtale av henne blir det lite viktig å framheve at det også fins et bilde tatt i profil. Sammenlignet med hva som var vanlig blant etnografer i denne perioden, må hans bruk av antropologiske portretter karakteriseres som moderat. Noe av det samme gjelder hans bruk av antropologiske målinger. At han utsatte dette til mot slutten av ekspedisjonen og da på et sted som var perifert $\mathrm{i}$ forhold til hovedstedene for feltarbeidet, kan tyde på at han ikke selv vurderte dette som et viktig element $i$ undersøkelsen, og de var i alle fall ikke «systematiske». I likhet med profilbilder var målinger en del av datidas etnografiske standardverktøy. Hans oppdragsgivere må ha forventet at han praktiserte hva han hadde lært under studiet.

Tilsynelatende er det og en spenning i hvordan Sergel karakteriserte de samene han møtte. $\mathrm{Vi}$ har gjengitt noen av hans positive og nærmest romantiske karakteristikker av enkeltpersoner, som kan generaliseres til å gjelde klær, sko, telt, mat, levevis, ja, samisk kultur i sin alminnelighet. Især når det gjelder reindriftsbefolkningen og ikke minst kvinnene, gjentok Sergel hvordan han frydet seg over å betrakte dem og deres omgivelser. Han tok eksplisitt avstand fra spekulasjoner om at dette var et folk dømt til undergang, slik mange sosialdarwinister og andre samtidige vurderte «den samiske nasjon». ${ }^{55}$ Hvordan skal dette forlikes med formuleringene i rapporten til REM om samene som «nizshaia ras»" og «nizkoe plemia»? Myklebost oversetter dette som «laveste rase», ${ }^{56}$ men kan det tenkes at en annen filologisk fortolkning stemmer bedre overens med utsagnets nære og generelle kontekst: «Personer med lav kroppshøyde som befinner seg nederst på den sosiale rangstige»? Neste setning i Sergels rapport om gjennomsnittlig kroppshøyde støtter en slik fortolkning. ${ }^{57} \mathrm{Vi}$ bør huske at marxismen sto sterkt 
i intellektuelle miljøer i Russland også før revolusjonen, og for dem var over- og underordning av mennesker i rasekategorier lite viktig. At Sergel også tenkte i sosiale kategorier, går klart fram av hans beskrivelse av de to sjøsamebrødrene i Iggaldas - den ene fattig og den andre framgangsrik. En sammenligning av rase- og andre klassifikasjonsbegreper hos etnografer fra ulike land gjennom flere tiår er en interessant og komplisert oppgave som krever et format langt ut over en kort artikkel.

I sum vil vi gjenta vår karakteristikk av Sergel som en human og empatisk forsker med god innsikt og ferdighet i metoder for etnografisk feltarbeid. I den foreløpig siste russiske publikasjonen om Sergels virke - den første hvor hans biografi blir gjengitt på en tilforlatelig måte blir han innlemmet i en generasjon av samtidige romantikere: ««Professor Volkov» ... klarte å gjøre ham ... til profesjonell etnograf. [Gjennom reisene] framsto han som en ung romantiker, som en moden mann og skarp observatør ... en fremragende forsker og talentfull skribent ...». ${ }^{58}$ Gitt de nødvendige ressurser var han også en produktiv etnograf som viste stor evne til å ta seg fram på egen hånd og kunne utrette mye på kort tid. Hans arbeider fortjener å bli mer kjent blant forskere og blant de urfolkene han studerte, ikke stigmatisert og fremmedgjort i teoretiske vendinger. Hans skrifter bør bli systematisk vurdert opp mot andre etnografers rapporter fra feltarbeid i de samme områdene og komplementært kildemateriale. For at det skal bli realistisk, bør rapporten og boka oversettes.

\section{Litteratur}

Baglo, Cathrine 2011: På ville veger? Levende utstillinger av samer i Europa og Amerika. Doktoravhandling, Universitetet i Tromsø. http://www.ub.uit.no/munin/handle/ 10037/3686

Blix, Erik S. 1988: Karasjokslekter. Karasjok.

Davydov, Ruslan 2010: «Narodnyie Volneniia v severnoi Norvegii, slukhi o russkoi ugroze i massovoi izmene norvezhsev v pol'zu Rossii (po doneseniiam russkogo konsula O. Vizelia leta 1903.» [Vizels rapport om folkelig uro i det nordlige Norge, rykter om den russiske fare og opinion til fordel for Russland sommeren 1903 ...] Zhivushchie na Severe. Al'manakh Murmanskogo gosudarstvennogo gumanitarnogo universiteta. [Liv i Nord. Murmansk statshumanistiske universitets almanakk]. Murmansk, s. 79-87.

Glavatskaya, Elena 2009: «The Polar Urals' religious landscape in the 1920's: Images in the photographic collections of the Urals State Archive (GASO)». Jahrbücher für Geschichte Osteuropas (57). Stuttgart, s. 205-220.

Glavatskaya, Elena og Thorvaldsen, Gunnar 2013: «Sergej Sergel's Field Research in Northern Norway and Finland - Contextualizing Early $20^{\text {th }}$ Century Sami.» Arctic Anthropology (1) s. 105-119.

Ivanovskaia, Natal'ia 2011: S. I. «Sergel' I ego nauchnoe nasledie». [S.I. Sergel' and his scientific heritage] I: Ivanovskaia, Natal'ia og Chuv'iurov, Aleksandr Sergej Ivanovich Sergel' Etnograph I puteshestvennik [Sergej Ivanovich Sergel' - etnograf og reisende]. St Petersburg, s. $5-23$.

Jåstad, Hilde 2011: «Endring i samisk og norsk husholdsstruktur: Nord-Troms og Finnmark i perioden 1865 til 1900». Historisk tidsskrift 90(1) s. 33-61.

Koz'min, Valerian 2005: Iz istorii etnographicheskogo obrazovaniia v Sankt-Peterburgskom universitete [Fra historien til etnografiutdanningen i St Petersburgs universitet]. I: VI Congress etnologov I antropologov Rossii/ SanktPeterbug, 28 iiunia - 2 iiulia 2005: Tezisy dokladov. St Petersburg, s. 420. [Rapport fra den VI. kongressen til russiske etnologer og antropologer i St Petersburg 2005].

Kuropjatnik, Marina 1996: «Sergej Sergel and his visit to Finnmark». Acta Borealia (2) s. 125-34.

Kuropjatnik, Marina 2004: Kollektsii po etnographii saamov. [Samlinger om samisk etnografi]. I: Materialy po etnografii. Tom II. Narody Pribaltiki, Severo-Zapada, Srednego Povolzh'ia i Priural'ia. [Etnografisk materiale, bind II. Folk i Baltikum, russisk nord-vest, Volga-området og det vestlige Ural]. St Petersburg.

Lie, Einar og Roll-Hansen, Hege 2001: Faktisk talt: Statistikkens historie i Norge. Oslo, Universitetsforlaget.

Lindin, Leif og Rydving, Håkan 2007: Samisk kyrkohistorisk bibliografi. Umeå: Centrum för samisk forskning.

Myklebost, Kari 2005: «In search of essential Lapland: The ethnographic travels of Jens A. Friis in northwest Russia (1867) and Sergey Sergel in Northern Norway (19071909).» I: Russia - Norway. Physical and Symbolic Borders. Jazyki slavjanskikh kul'tur s. 140-157.

Myklebost, Kari 2008: «V poiskah nastoiaschei Laplandii. Etnographicheskie ekspeditcii Iensa Friisa po russkomu severo-zapadu (1867) i Sergeia Sergelia po severnoi norvegii (1907-909 gg.).» [Se forrige referanse]. Vestnik 'Berentc-centra' Murmanskii Gosudarstvennyi pedago- 
gicheskii universitet. [Murmansk statspedagogiske universitet 'Barents-Center' Newsletter]. (7) s. 73-92.

Sergel, Sergej 1907a: «A letter to Volkov F.K. from 22.09.1907.» I REMs arkiv. Fond 1. Opis'.2. Delo 566. List 38-39.

Sergel, Sergej 1907b: Ekskursiia k norveshzbskim lopariam. [Ekskursjon til de norske samer]. Manuskript i REMs arkiv. Fond 1. Opis'.2. Delo 568. Trykket i Sergel 2004. Sergel, Sergej 1927: God Kochevki s lopariami. Ocherki prirody i liudei. [Et år på reise med samer. Essays om folk og natur]. Moskva-Leningrad.

Sergel, Sergej 1928: V Zyrianskom krae. [I syrianernes land]. Moskva -Leningrad.

Sergel, Sergej 2004: «Ekskursiia k norveshzhskim lopariam.» [Ekskursjon til de norske samer]. Publikasjon fra the REMs arkiv, redigert av Zadneprovskaia, Aleksandra. I: Materialy po etnografii. Tom II. Narody Pribaltiki, Severo-Zapada, Srednego Povolzbia I Priural'ia. [Materiale om etnografien i Baltikum, russisk nord-vest, Volgaområdet og det vestlige Ural]. St Petersburg, s. 284-334.

Shnukal, Anna 1998: «N.N. Miklouho-Maclay in Torres Strait». Australian Aboriginal Studies. September 22.

Steen, Adolf 1986: Kautokeinoslekter. Oslo: Norsk folkemuseum.

Thorvaldsen, Gunnar 1996: Registrering og bruk av historiske persondata. Oslo.

Thorvaldsen, Gunnar 2004: «Borte fra heimen. Om midlertidig fraværende og tilstedeværende i seint 1800-tall». Heimen s. 287-300.

Thorvaldsen, Gunnar 2007: «An International Perspective on Scandinavia's Historical Censuses». Scandinavian Journal of History 32(3) s. 237-257.

Vizel, Oskar 1909: Sbornik norvezhskikh uzakonenii kasaiushchikhsia torgovli i promyslov russkikh poddannykh v Severnoi Norvegii. [Kompendium om norsk lov om russisk handel i det nordlige Norge]. St Petersburg.

Zadneprovskaia, Aleksandra 2004: «S.I. Sergel. Ekskursiia k norvezhskim lopariam». [Introduksjon i publikasjon av Sergej Sergels manuskript 'Ekskursjon til de norske samer]. I: Materialy po etnografii. Tom II. Narody Pribaltiki, Severo-Zapada, Srednego Povolzbia I Priural'ia. [Materiale om etnografien i Baltikum, russisk nord-vest, Volgaområdet og det vestlige Ural]. St Petersburg, s. 280-283.

\section{Noter}

1 Kuropjatnik 1996, 132.

2 Myklebost 2005, 140.

3 Smst. 141.

4 Det er en utbredt misforståelse at instituttet kun utdannet geografer. Vi går derfor i detalj om dette og gjengir sitatet i original: «B 1887 г. на физико-математическом факультете СПбГУ была образована кафедра географии и этнографии. Э.Ю. Петри, начинает читать систематические курсы по антропологии, которую он понимал как науку о развитии человеческой культуры. С 1907 г. эту традицию продолжил Ф.К. Волков, который рассматривал этнографию как триединую науку, включающую в себя физическую антропологию, этнографию и палеоэтнографию» (Козьмин 2005 420).

5 Ivanovskaia 2011, 18.

6 Shnukal 1998.

7 Ivanovskaia 2011, 9.

8 Glavatskaya 2009.

9 Østsamisk minoritet bosatt i grensetraktene mellom Russland, Finland og Norge.

10 Konfidensielt arkiv for Finnmark fylke 1867-1928, mappe 2704 1907-1917. I Statsarkivet, Tromsø.

11 Kungl. Utrikesdepartementet. Grupp: 44, Afd: D, Mål: 98 i Sveriges Riksarkiv. S-2259 Utenriksdepartementet, serie D, boks nr. 28 i Riksarkivet, Oslo.

12 Davydov 2010, 79-87.

13 Vizel 1909.

14 Henholdsvis 1996, 125 og 1927, 5.

15 Sergel 1927, 10.

16 Smst. 12.

17 Smst. 13.

18 Kuropjatnik 2004.

19 Sergel 1927, 21.

20 Ifølge spesiallistene over hjemvendte norskamerikanere i 1910-tellinga.

21 Sergel 1927, 24f.

22 Se spesiallistene over hjemvendte norskamerikanere i 1910-tellinga og http://www.polarhistorie.no/personer/ Balto,\%20Samuel

23 Sergel 1927, 37.

24 Smst. 33.

25 Chaga er en sopp på bjørketre som heter det samme på russisk. Kjent middel i naturmedisin, se http:// www.rolv.no/urtemedisin/medisinplanter/inon_obl.htm besøkt 20.01.2013.

$262004,328$.

27 Sergel 1927, $41 \mathrm{f}$.

28 REM. Fond 1. Opis'.2. Delo. 75; (Zadneprovskaia 2004: 282).

29 2004, $304 \mathrm{f}$.

30 Sergel 1927, $52 \mathrm{f}$.

31 Smst. 60.

32 Smst. 67.

$331996,26$.

34 Jåstad 2011.

35 Sergel 1927, 93.

36 Steen 1986.

37 Statsarkivet i Tromsø har informative internettsider om blant annet slektskapsforholdene, se http://www.arkivverket.no/kautokeino-opproret. Ellen er gjort til opprørets hovedperson i filmen fra 2008. Hennes tragiske 
skjebne illustreres og i folketellinga 1875 hvor fødselsåret oppgis til 10 år for tidlig.

$382004,325$.

$391927,73,97 \mathrm{f}$.

40 Thorvaldsen 2004

41 Sergel 1927, 95.

42 Smst. $95 \mathrm{f}$.

43 Sergel 2004, 291-293.

44 Sergel 1927, 98.

45 Smst. $110 \mathrm{f}$.

46 Sergel 2004, 301, 319.

47 Blix 1988, 456-458.
48 Baglo 2011, 75-80.

49 Sergel 1927, 123

50 Glavatskaya og Thorvaldsen 2013.

51 Sergel 1927, 139-141.

52 Smst. 144.

53 Smst. $144 \mathrm{f}$.

54 Myklebost 2005, 146

55 Sergel 2004, 302; 1927, 23 f, 107 f, 122.

562005,150

$572004,296$.

58 Ivanovskaia 2011, 18 